\title{
Respecting students: Abusive classroom teacher verbal behaviour
}

\author{
Terry Hogan ${ }^{1}$, Carlo Ricci ${ }^{2}$ and Thomas G. Ryan ${ }^{3}$ \\ ${ }^{1}$ Nipissing University, Ontario, Canada (ORCID: 0000-0002-4487-5111) \\ ${ }^{2}$ Nipissing University, Ontario, Canada (ORCID: 0000-0002-4138-400X) \\ ${ }^{3}$ Nipissing University, Ontario, Canada (ORCID: 0000-0002-4073-0994)
}

\begin{abstract}
This qualitative study examined classroom Teachers verbal abuse by reviewing a sample of the decisions of the discipline committee of the Ontario College of Teachers (OCT). Data were collected from the Canadian Legal Information Institute (CANLII) online database, which provided a record of all the OCT discipline committee decisions, with supplementary data from Professionally Speaking, the magazine of the OCT, as well as the OCT's website. Data revealed that verbal abuse is present in Ontario classrooms, and measured responses and related methods of dealing with teacher misconduct are derisory at best and slowly evolving. Investigated cases of verbal abuse in the classroom were reviewed and illuminated the progress that has been made in dealing with Teacher verbal abuse in schools, while providing suggestions for improvement. Male Teachers are often offenders and the impact on all stakeholders is both lifechanging and serious. In sum, any delay in effectively dealing with complaints and disciplinary matters is unacceptable as it stands and must be fixed to protect students from abuse.
\end{abstract}

Keywords: Teacher behavior; Abuse in classrooms; Teacher discipline; Legal issues

Article History: Submitted 9 August 2019; Revised 24 October 2019; Published online 26 October 2019

\section{Introduction}

Our purpose was to examine how we as a society are currently addressing verbal abuse of students by elementary and secondary teachers in the education system of Ontario. To reach this objective it was necessary to critically examine the decisions of the discipline committee of the Ontario College of Teachers (OCT). The review and examination process undertaken herein illuminated teachers who do not respect the rights of students; in particular those educators who yell at students: And we all know that, "there is no place for the yelling teacher in modern education" (Wheeler, 1935, p. 12).

Arguably, educational systems attempt to ensure that teachers are educating students appropriately, and while ensuring the safety and security of students and from external threats, yet there is still the question of keeping students safe from those who are placed there to teach. In response to these goals Canadian stakeholders such as Alberta Education administers a survey to their students that includes one question which asks: "Are you treated fairly by adults in your

Address of Corresponding Author

Thomas, G. Ryan, Ph.D., Nipissing University, Faculty of Education, 100 College Drive, Box 5002, North Bay, ON, Canada.

$\triangle$ thomasr@nipissingu.ca

How to cite: Hogan, T., Ricci, C., \& Ryan, T. (2019). Respecting students: Abusive classroom teacher verbal behaviour. Journal of Pedagogical Research, 3(3), 151-165. 
school?" The students respond by filling in a bubble for Yes, No, or Don't know. The results are remarkably consistent across grades and over different years, with 80 to $84 \%$ of students from grades four to 12 indicating they are treated fairly by adults in their school for the years 2014-2018 (Alberta Education, 2018). Similarly, the Ontario Ministry of Education sends out a student survey on school climate, which addresses issues of discrimination, harassment, and bullying, but it is almost entirely focused on peer-to-peer bullying and discrimination. The survey does ask about verbal abuse, but the questions are worded in such a way that it would only apply to students verbally abusing other students (Ontario Ministry of Education, 2018a).

In 2017, the Ontario Student Trustees Association made a survey available to all Ontario secondary students. It was conducted online anonymously and received over 8000 responses, although the total number of students is unknown as some of them were duplicate responses. The survey contained a paragraph response section for a question on how the education system could better prepare students for life and work after school, as well as a question on how their education compared to the education at other schools. Less than half the students chose to submit paragraph responses, but even when unprompted to comment specifically on teachers, there were over 500 responses that did mention teachers; many detailed how they were treated by teachers in their school. While there were some positive comments, many respondents talked about racism, some mentioned discouraging language and the fact that teachers made fun of certain students, causing students to want to avoid attending school. One student commented that surveys should ask about specific teachers, however, a question about teachers or education quality in general may garner vague responses such as "good," and therefore minimally helpful (Ontario Student Trustees Association, 2017).

\subsection{Verbal and Emotional Abuse}

Yelling and other forms of verbal abuse occur with alarming frequency in Canada (Brendgen, Wanner, \& Vitaro, 2006). In Ontario, regulation 437/97 made under the Ontario College of Teachers Act, states that abusing a student verbally is an act of professional misconduct, although teachers are rarely brought to a disciplinary meeting solely based on verbal abuse, as is seen in the public records. The disciplinary committee has confirmed that shouting at students is verbal abuse: "The mere fact of shouting at students constitutes verbal abuse, in the circumstances of this case" (Ontario College of Teachers $v$ Glazer, 2018, para. 92). But it is unclear whether teachers themselves view it that way.

Stillman, (2013) while examining gentrification and integration in schools, interviewed parents who were removing their children from schools and found: "They were put off by near-constant yelling-from principals, teachers, school aides" (p. 37). Stillman later provides part of an interview with a parent: "Erich used the word 'insanity' to express his disdain for the yelling and strictness norm, which he attributed primarily to the administration: 'There was just a lot of yelling in the halls, a lot of screaming at the kids'" (p. 38).

Nesbit and Philpot (2002) define emotional abuse suggesting it is carried out with words, gestures, and policies, and can happen to individuals, or groups, of children or adults. Aluede, Ojugo, and Okoza (2012) go further in calling it "a form of substantiated child abuse . . . the systematic psychological tearing down of another human being" (p. 29). When described in such a way, it is perhaps unsurprising that there would be an unwillingness on the part of educational authorities to participate in research that may illuminate such behaviour.

\section{Background}

Ungar, Tutty, McConnell, Barter, and Fairholm (2009), working in a Canadian context, suggest that less than $25 \%$ of youth who have suffered some form of emotional, physical, or sexual abuse report their abuse, and that those abused by a family member, and those that suffer physical abuse are most likely to report. If students who are being verbally abused by a teacher fail to report, it could be a contributing factor to the lack of attention given to the subject. Twemlow, Fonagy, and Sacco 
(2004) found that administrators will avoid dealing with teachers who bully students out of fear of upsetting the teachers' unions and causing difficulty in hiring new teachers. Twemlow et al. (2004) discovered that even teachers, who may recognize the impropriety of another teacher's actions, may be reluctant to complain out of a sense of loyalty to their colleagues, or a fear of being shunned. While no doubt created with the best of intentions, some teachers associations' codes of conduct often explicitly forbid criticism of another teacher without first informing them in person, or in writing (Alberta Teachers' Association, 2004; British Columbia Teachers' Federation, 2017; Elementary Teachers Federation of Ontario, 2019; Ontario English Catholic Teachers Association, 2018; Saskatchewan Teachers' Federation, 2006), this has a unnerving effect on any criticism of another teacher. While School Board codes of conduct generally make exceptions for cases of sexual abuse, or where student safety is an issue, teachers may not be as comfortable reporting cases of verbal abuse where the threat to student safety is not as readily visible or demonstrated. As Webster, O'Toole, O'Toole, and Lucal (2005) found in cases of suspected child abuse, teachers are more likely to report to child protective services cases where they suspect sexual abuse than cases where physical abuse is suspected, and are more likely to report when the abuse described is more serious. This is in keeping with the idea of forms of abuse being ranked in terms of seriousness. The same study found that teachers were less likely to report in situations where they thought there would be problems for the child, or problems for themselves as the teacher of the child. A further complicating factor the authors mention is the fear of having to make a court appearance or testimony. If teachers are less likely to report cases of suspected abuse involving parents because of a reluctance to testify, it is not unreasonable to think they would be just as reluctant to report and provide testimony against a colleague, if not more so. There is also a general reluctance on the part of many to criticize public education in general, because it is seen overall as beneficial to society and a 'public good' in many senses.

There may be an underrepresentation of the subject in research because of a perception among some that yelling is harmless and thus needs no study. Atiles, Gresham, and Washburn (2017) refer to teachers yelling simply as a response to children's misbehaviour, akin to re-direction, and one step down from a referral to the principal's office. But if we are concerned about subjects such as peer-to-peer bullying, we must also concern ourselves with teachers' behaviour towards their students, because as White, Jones and Sherman (1998) demonstrated, teachers' actions towards a student can affect other students' perception of that student, so yelling at a student could encourage them to also belittle that student. Nesbit and Philpott (2002) argue that most of the abuse that occurs in the classroom is subtle and the teacher is unaware that they are doing it. Yet, Babad, Bernieri, and Rosenthal (1991) showed that students as young as grade four could quite accurately determine whether a teacher had low expectations or high expectations of a student based on only short audio, visual, or both audio and visual clips of teachers, and they could also tell teachers fondness for students. So, whether overt or subtle, negative attitudes towards children are perceived by both the receiving students, and those that are bystanders in the classroom.

The deleterious effects of verbal aggression by teachers are numerous. Bekiari and Petanidis (2016) showed that verbal aggression from teachers was linked to less effort and interest, higher tension, and even made the students rate teachers as less physically attractive.

\subsection{Canadian Context}

Recently an Alberta teacher was found guilty of humiliating and belittling students for 36 years and a professional disciplinary hearing may revoke her certification and impose a $\$ 32,500$ fine (French, 2018, p.1). While this situation is a precedent setting benchmark, Brendgen et al., 2006, have concluded that "many adults mention past incidences of verbal abuse by the teacher as the most overwhelmingly negative experience in their lives" (p. 1585), they also found that verbal abuse by the teacher in elementary school was significantly related to subsequent delinquent behaviour and academic difficulties in early adolescence. 
Konishi, Hymel, Zumbo and $\mathrm{Li}$ (2010) found that reading and math achievement was positively related to student teacher connectedness and negatively connected to school bullying. Using a sample of survey data from over 27,000 students collected for PISA testing, and data from over 1000 principals, their research revealed how positive relationships with teachers help results, but did not specifically address negative teacher relationships. Brendgen, Bukowski, Wanner, Vitaro, and Tremblay (2007) discovered that verbal abuse by the teacher is negatively correlated with school performance, attainment of a high school diploma, perceived scholastic competence, and perceived behavioural competence in grades five through seven while being strongly positively correlated with behavioural problems at age 23. Their study, conducted over 17 years, involved 399 students from Quebec, and it also showed that males, and those from low socio-economicstatus (SES) households, were more likely to be victims of teacher verbal abuse. Wanner et al. (2007) found there was no policy in regard to verbal abuse by a teacher. Educators interested in social justice should thus be concerned about the effects of verbal abuse in the classroom, as they seem to be both disproportionately aimed at students from low SES backgrounds, and through lack of education, could result in perpetuation of a low SES adulthood.

\subsection{Ontario Regulation 437/97 Professional Misconduct}

The Ontario College of Teachers has recognized verbal abuse of students as an act of professional misconduct since 1997 when Ontario Regulation 437/97: Professional Misconduct was enacted under the Ontario College of Teachers Act (1996). Regulation 437/97 lays out the definitions of professional misconduct as they apply to teaching in Ontario. The first version of the regulation, in force until May 2008, had only one subsection under which physical, sexual, verbal, psychological, and emotional abuse of students were all included. The regulation went unchanged until May 5, 2008 when Ontario Regulation 134/08 went into force, changing paragraph seven of the regulation which dealt with teacher abuse of students. The new version of Regulation 437/97 separated the various forms of student abuse into four separate categories, each with their own subsection. In this way a teacher could be accused of verbal abuse separately from emotional, physical or sexual abuse. Regulation 437/97 continues to list the following as professional misconduct " 7 . Abusing a student verbally. 7.1 Abusing a student physically. 7.2 Abusing a student psychologically or emotionally. 7.3 Abusing a student sexually." Subsequent rulings by the discipline committee have created a collection of precedent-setting case law that further sets out definitions applicable to the various forms of abuse. So, while 'verbal abuse' is not defined by the misconduct regulation, cases of swearing by a teacher in the classroom have been shown to be verbal abuse in more than one case.

telling a student to 'shut the fuck up,' telling a student that he is 'not afraid to hit a kid,' telling students to shut up, swearing in class, and commenting on a student's weight were all forms of verbal abuse. The above-noted statements by the Member were demeaning and threatening to students. (Ontario College of Teachers $v$ Reinders, 2017, para. 79)

The case of Ontario College of Teachers $v$ Gionest, (2017) states "paragraphs 3, 5 and 6 of the Agreed Statement of Facts and Guilty Plea demonstrate that the Member abused a student or students verbally, contrary to Ontario Regulation 437/97, subsection 1(7)." where paragraph six that is referenced states "During the 2011-2012 academic year, the Member used the words "shit" and "hell" in error in the presence of students." It is unclear whether the committee in its ruling meant that the actions listed in paragraph six alone would constitute verbal abuse, or only when combined with the actions in the other paragraphs, but it is clear from the combination of the two rulings that swearing in the presence of students is grounds for a finding of verbal abuse.

\subsection{The Complaint Process}

When a complaint is submitted to the OCT, a number of steps must occur before a discipline hearing is held and any decision would appear on the CanLII website. All complaints are first examined to determine if they are best handled at the level of the college, or better dealt with at the school or board level, as the OCT only considers complaints that are related to professional 
misconduct, incompetence, or incapacity. The investigation committee of the college will also refuse to consider a complaint if, in its opinion

(b) the complaint is frivolous, vexatious, an abuse of process, manifestly without substance or made for an improper purpose; or

(c) the complaint does not warrant further investigation or it is not in the public interest to investigate the complaint further, and that determination was made in accordance with the regulations. (Ontario College of Teachers Act, 1996, clause 26, 2)

The legislation is not clear as to how the committee determines whether a complaint is frivolous, vexatious, or otherwise unworthy of investigation. If the investigation committee does investigate a complaint and determines that it is valid, the member is informed of the complaint and may respond within 35 days. The complaint may result in the member receiving a written caution, or a caution from the investigation committee in person if the issue does not require a disciplinary hearing, but in the opinion of the committee, still needs to be addressed by the college. If not disposed of by one of the previous stages, the complaint is then referred to one of three different streams, the complaints resolution program, the discipline committee, or the fitness to practice committee.

\section{Method}

\subsection{Research Design}

Our multiple case study mode (Stake, 2006) was deemed appropriate wherein multiple data sources (Flyvbjerg, 2011), for each case were used (Crowe et al., 2011) and only the publicly available data from the Canadian Legal Information Institute (CanLII) website, with supplements from Professionally Speaking, as well as the OCT website was utilized.

\subsection{Participants and Data Collection}

200 of the published decisions of the OCT's discipline committee were reviewed. Out of a total of 1124 published decisions available we examined the first four years of available decisions, from 1998 to $2002(n=112)$, and also the 16 most current months of decisions available at the onset of our research, from April 2017, to July $2018(n=88)$. The time frames were chosen in order to examine differences in the way discipline matters were handled in the early days of the OCT as compared to now, particularly in light of the changes that were enacted after the publication of the LeSage Report. The time frames produce equivalent sample sizes that were large enough to provide a picture of the overall situation, but small enough to be examined in detail (Poggenpoel, 2005). Selecting 200 decisions allowed for 31 cases of verbal abuse, 13 of which were decisions where verbal abuse was the primary complaint addressed in the hearing. The 200 decisions examined involve 200 different teachers, which should represent over $20 \%$ of the teachers who have had decisions rendered by the discipline committee. There is uncertainty surrounding the total number of cases the discipline committee has seen; the 1124 individual decisions of the discipline committee do not correspond to 1124 different teachers, as many cases have multiple entries in the database, due to hearing postponements and adjournments (Ontario College of Teachers v. Guirand, 1998a, and Ontario College of Teachers v. Guirand, 1998b), separate hearings for decisions and penalties in some cases (Ontario College of Teachers v. Markson, 2001a, and Ontario College of Teachers v. Markson 2001b) and in other cases double entries for translations of rulings in French (Ontario College of Teachers v. Mosley 1998, and Ordre des enseignantes et des enseignants de l'Ontario c. Mosley 1998). The 2017 Annual Report for the OCT (Ontario College of Teachers, 2018) lists a total of 1120 cases heard by the discipline committee between 1998 and 2017, of which 226 had the notice of hearing withdrawn, which makes for a total of 894 cases, and yet the OCT website lists 1040 different cases on its decisions website, a discrepancy not accounted for by the 72 decisions issued in 2018. The Lesage report also indicated that 14 decisions of the discipline committee were subject to a 'quarantine' whereby the decisions were not made publicly available (Lesage 2012, p 60). The OCT states on its website that "The College's Discipline Committee decisions are available to the 
public. Once the conditions of the decision have been met, they will be removed in accordance with the Protecting Students Act" (Ontario College of Teachers, 2019b, para. 1), therefore the amount listed on the OCT website should be less than the total numbers indicated elsewhere. As no sources indicate a number of cases greater than 1192 (1120 indicated in the 2017 Annual Report, plus 72 from 2018), and none would indicate a number less than 894, the true number of cases must be assumed to lie somewhere within that range.

\subsection{Data Analysis}

For each of the 200 cases examined, it was determined by a close reading of the proceedings whether the allegations involved verbal abuse, physical abuse, sexual abuse, criminal activity, financial misconduct, or some combination thereof. The cases that did not involve abuse, criminal activity or financial misconduct were all labeled simply as professional misconduct; these included teachers who falsified their qualifications, improperly handled provincial testing, failed to report cases of suspected abuse, as well as cases where the specific allegations were not revealed. For decisions rendered prior to the 2008 change in Ontario Regulation 437/97, a close reading of the allegations was necessary to determine if the case involved verbal abuse. For decisions rendered after the 2008 change in regulations, the subsections referenced in the allegations were used to determine if verbal abuse was alleged. The gender of the teacher in question was recorded as male or female, according to the pronoun used by the OCT in the decision.

\section{Results}

Reviewing the initial 200 cases there were multiple findings. The most visible was the preponderance of males relative to females, particularly when considered in comparison to their relative numbers in the teaching profession at large. Out of 200 decisions examined, 167 (83.5\%) were males, and $33(16.5 \%)$ were females. This is in comparison to the 235,705 members of the OCT in good standing as of 2017 , of which $26 \%$ were male, and $74 \%$ were female, with three teachers not choosing to be identified as either male or female (Figure 1). We did not specifically set out to study gender ratios of the teachers facing misconduct hearings, but the result was too striking not to be mentioned.

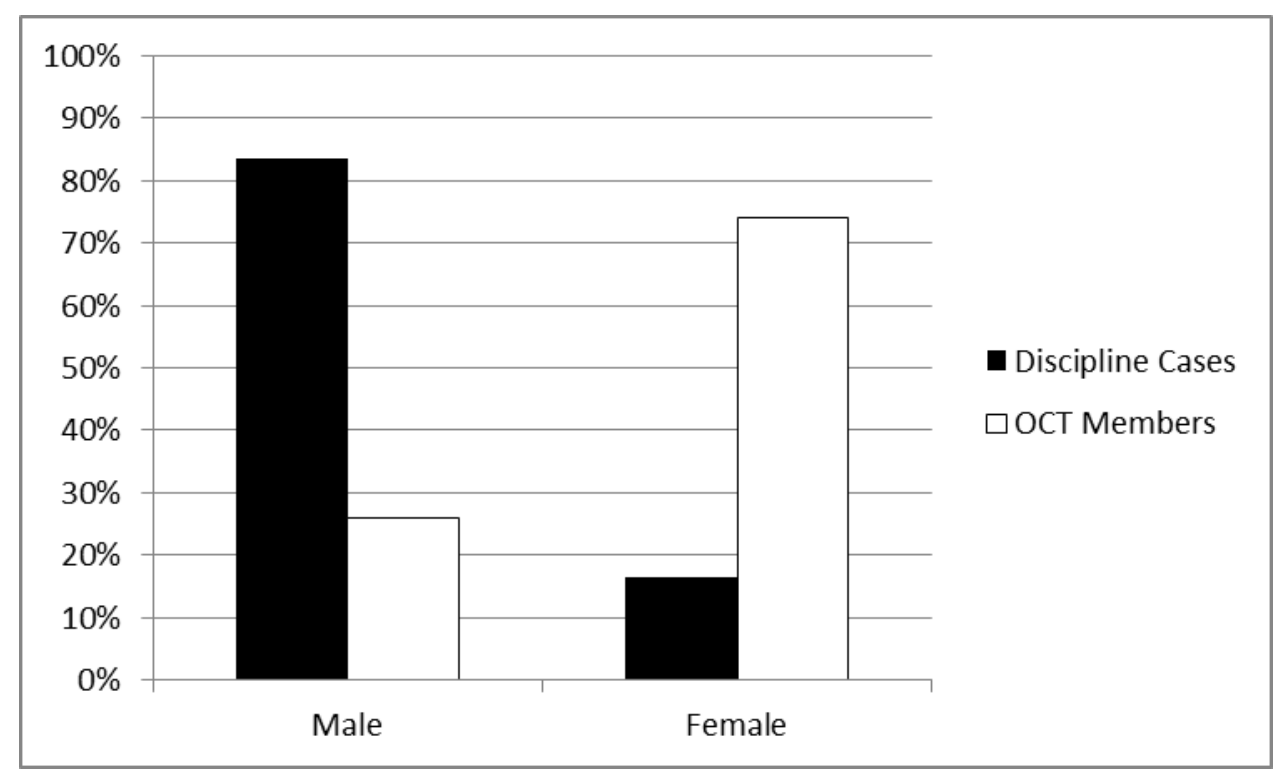

Figure 1. Percentage of OCT members identified as male and female and percentage of discipline cases involving male and female members

Another rather striking result was the difference in the types of cases brought before the discipline committee in the early period examined (1998-2002) versus the more recent period 
examined (2017-2018). Of the 31 cases involving verbal abuse, only six were from the early period, despite a slightly larger sample from that earlier period. In the older period, well over half the complaints were cases of sexual abuse, while in the more recent period they made up less than half of the complaints, as noted in figure two.

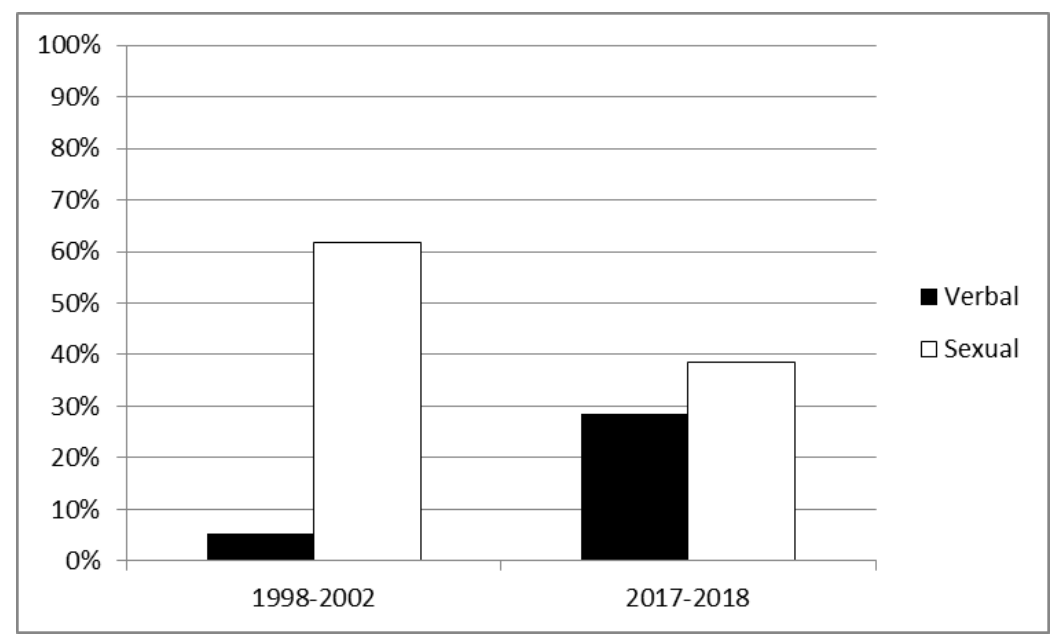

Figure 2. Percentage of discipline committee cases involving verbal and sexual abuse from 19982002 and from 2017-2018

Part of the preponderance of sexual abuse cases in the early period likely comes from the hearing of historical complaints that had already been tried in the courts, and needed to be formally dealt with by the OCT, as in the case of Ontario College of Teachers $v$ Kuneman (1998) where the teacher had already been criminally convicted and dismissed from their teaching job two years prior to the hearing, which was also before the discipline process had been finalized and enshrined in the legislation and regulations. It should also be noted that although there was a relative or percentage decline in the number of sexual abuse cases heard in the later period, that does not correspond to an absolute decline in the number of cases, as there were more disciplinary cases heard every year in the later period. For example, of the 22 discipline committee hearings from the year 2000 for which records are available, 17 involve cases of sexual abuse, and in the closing six months of 2017, there are 49 discipline committee hearings with public records, and 22 cases of sexual abuse. So, while the percentage of cases dealing with sexual abuse has declined, the number of cases dealing with sexual abuse has actually increased in absolute terms as noted in figure three.

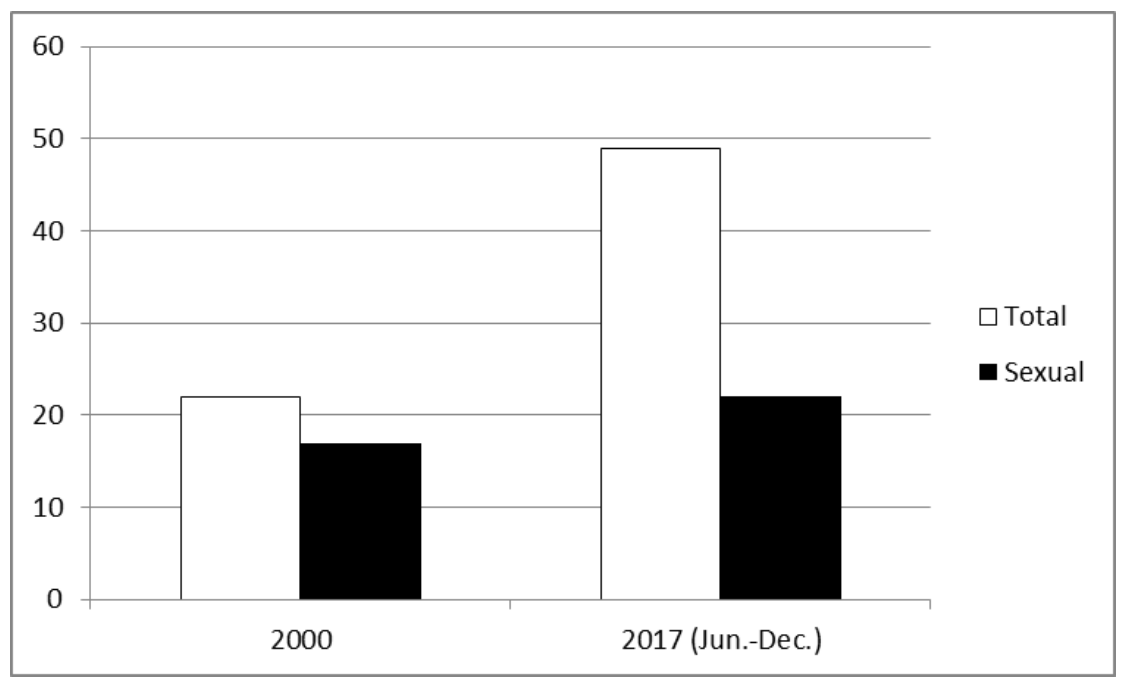

Figure 3. Total number of OCT discipline cases and the number of cases involving sexual abuse for the year 2000 and the first six months of 2017 
With verbal abuse, both the absolute number of cases dealing with verbal abuse, as well as the percentage of cases dealing with verbal abuse have increased drastically from the early years of the OCT to the present. It should also be noted that of the 13 cases for which verbal abuse was the main or only complaint, none of them occurred in the period from 1998-2002. All of the cases of verbal abuse from the earlier period involved multiple complaints including other forms of professional misconduct or physical violence.

In the 31 cases where verbal abuse was indicated, three main themes emerged that accounted for the behaviour: ignorance and inexperience; frustration and mental health; and inadequate supervision, reporting, or governance. Examination of the 13 cases where verbal abuse was the main or only complaint revealed that most cases fit into one or more of the three categories and that is how we have classified them. There was only one case we were not able to assign to one of the three categories and so that was labelled as other in table one.

Table 1.

Case Studies of Verbal Abuse Examined

\begin{tabular}{ccccc}
\hline Case \# & Date Heard & M/F & Year Licensed & Cause \\
\hline 1 & $05 / 17$ & $\mathrm{~F}$ & 1987 & $\mathrm{M}$ \\
\hline 2 & $06 / 17$ & $\mathrm{M}$ & 1976 & $\mathrm{~S}$ \\
\hline 3 & $06 / 17$ & $\mathrm{M}$ & 1974 & $\mathrm{~S}$ \\
\hline 4 & $08 / 17$ & $\mathrm{M}$ & 1985 & $\mathrm{~S}$ \\
\hline 5 & $10 / 17$ & $\mathrm{M}$ & 1998 & $\mathrm{I}$ \\
\hline 6 & $10 / 17$ & $\mathrm{M}$ & 2010 & $\mathrm{M} / \mathrm{S}$ \\
\hline 7 & $11 / 17$ & $\mathrm{~F}$ & 1992 & $\mathrm{I}$ \\
\hline 8 & $12 / 17$ & $\mathrm{~F}$ & 2004 & $\mathrm{I} / \mathrm{S}$ \\
\hline 9 & $01 / 18$ & $\mathrm{M}$ & 2005 & $\mathrm{O}$ \\
\hline 10 & $03 / 18$ & $\mathrm{~F}$ & 1994 & $\mathrm{I} / \mathrm{S}$ \\
\hline 11 & $06 / 18$ & $\mathrm{M}$ & 1994 & $\mathrm{I} / \mathrm{S}$ \\
\hline 12 & $06 / 18$ & $\mathrm{~F}$ & 1996 & \\
\hline 13 & $06 / 18$ & $\mathrm{~F}$ & 1970 & Inexperience;
\end{tabular}

\section{Discussion and Recommendations}

\subsection{Why Does Verbal Abuse Occur?}

One thing that is clear from the existing literature, and from the data reviewed is that verbal abuse does not occur solely because of bad teachers, or because teachers mean students harm. Teachers are, like all humans, complex creatures with varied facets of their emotional and psychological makeup (Fromuth, Davis, Kelly, \& Wakefield, 2015). Much like the students they teach, teachers have good and bad days, and can exhibit both good and bad behaviour, frequently within the same class. McKenzie (2009) met with a group of what were considered by their administrators to be average or better teachers, and in her discussions inadvertently found that they had all engaged in verbal and emotional abuse of students at some point. Recently a teacher was recorded verbally and emotionally abusing a kindergarten student during the same year she was named, 'Teacher of the Year' by her school (Wright, 2018). Teachers, parents and administrators all need to be made aware of the seriousness of the consequences of verbal abuse. What may be a momentary lapse in judgement for a teacher can become a life-long source of impairment for a student (Fromuth, et al., 2015). Teachers need to be given the training to deal effectively with issues of personal frustration and classroom discipline, and administrators need to properly supervise and work with the teachers in their schools to ensure that they are not committing acts of abuse. While being sympathetic to the needs and frustrations of teachers, we must also ensure that proper governance 
and disciplinary structures are in place, as while a teacher may get a second chance at teaching, or get a second career, each student is only given one childhood.

Racism was mentioned in far too many cases to be ignored. In the case of Ontario College of Teachers $v$ Manga (2017) the teacher made culturally insensitive remarks about no less than 15 different ancestries. In the case of Ontario College of Teachers $v$ Gionest (2017), the teacher made culturally insensitive remarks about Muslim students and black students, as well as using derogatory names for white students. The discipline committee in the case of Ontario College of Teachers $v$ Glazer (2018) also found the teacher guilty of racist comments towards black students. Without providing an exhaustive list of all incidents of racism as this would exceed the word limitations of this article, we note that there are more than those listed here, and that they occurred in both time periods examined. These cases all occurred well after the Ontario Ministry of Education and Training released a 52 page document Antiracism and Ethnocultural Equity in School Boards (1993). The document stated: "Boards shall require teachers to include antiracism and ethnocultural equity objectives in their long-term and short-term program and lesson plans" ( $p$. 18). While it is unclear how strictly those provisions were enforced, the document also stated that "effective change can be achieved only through collective action by all those involved in the school system: trustees, superintendents, students, and the community" (p. 6). Montgomery (2013) argues for effective critical pedagogies to combat racism, yet we have to first acknowledge the pervasiveness of racism in our society. Carr (2008) in calling for a more holistic and inclusive education system reminds us that "anti-racism involves a political engagement that surpasses symbolic measures" (p. 11) and laments the lack of resources currently devoted to combating racism in our education system. From my partial examination of the discipline committee data, it is obvious that racism is being perpetuated in some cases by the very teachers who should be tasked with fighting it.

The available data do not specifically record and address who are the victims of verbal abuse, but it is evident from the reported comments of the teachers involved that minority students have suffered verbal abuse from teachers in some of the cases (Fromuth, et al., 2015). Previous research has shown that certain forms of discipline are used disproportionately with minorities and students from lower socio-economic backgrounds (Ryan \& Goodram, 2013) and it is possible that verbal abuse is employed in a similarly discriminatory fashion. The proceedings of discipline committee hearings are purposely limited in certain details in order to protect the identity of students, but to take a more active stance against racism, as well as to provide transparency, the characteristics of student victims of teacher abuse should be recorded and at the very least reported in aggregate.

The persistent reoccurrence of homophobia was another unexpected result that came out of my research. In at least six cases, (Ontario College of Teachers v Blake, 2018; Ontario College of Teachers $v$ Caswill, 1999; Ontario College of Teachers v Fernandes, 2017; Ontario College of Teachers v Korjus, 2001; Ontario College of Teachers v Lewis, 2017; and Ontario College of Teachers v Manga, 2017) students or teachers were subject to various homophobic remarks. It was evenly split in that three cases involved teachers being subject to discrimination or harassment based on their sexual orientation, and the other three cases involved students suffering disparaging or inappropriate remarks at the hands of teachers.

Vaaland (2016) addresses teacher authority in depth, and concludes: "an authority figure that treats his or her followers disrespectfully... will lose legitimacy" (p. 13). And also "pupils give authority to teachers who deserve it and take authority away if teachers no longer deserve it" ( $\mathrm{p}$. 13). It is up to teachers themselves, and the profession in general, to create and maintain the image of teachers as professionals with the knowledge, education, and training that imbues them with the authority that should be respected by students and parents alike.

The preponderance of males in discipline committee hearings is also a cause for concern. For decades, various educational organizations have recognized the proportionate lack of male teachers, and the proportion of male teachers has continued to decline in Ontario since the 
inception of the OCT (Ontario Ministry of Education, 1995ab; Ontario College of Teachers, 2004; Ontario College of Teachers, 2007a; Ontario College of Teachers, 2018). One recognized barrier to men entering the profession has been

a sense that it is somehow inappropriate for male teachers to be in contact with young children. Within the profession, it is well understood that this is not the case, yet the public impression remains, amplified by sporadic but high-impact news headlines, and thus imprinted on the public consciousness out of proportion to reality. (Ontario College of Teachers, 2004, p. 5)

If men continue to be brought before discipline hearings in numbers and proportions vastly beyond their number in the profession, the idea that men are somehow ill-suited to the profession will be perpetuated. If it is the case, as the data would seem to suggest, that males are more likely to commit professional misconduct, then there are implications for training, screening, selection, and supervision of teachers. Are there confounding factors other than simply being male that lead to male overrepresentation in the discipline hearings? Some male teachers have indicated that they are treated differently than female teachers by administration, namely being expected to handle more discipline, students with greater behavioural needs, and coach more sports (Parr \& Gosse, 2011) all of which could be factors in eventual findings of misconduct. Another troubling possibility is that males do not commit professional misconduct in such greater proportion to female teachers, but are more likely to be brought to disciplinary hearings. This would mean a large portion of professional misconduct is going unreported or is not brought to disciplinary hearings.

Verbal abuse of students is a global issue, consider Betweli (2013) who used survey data in Tanzania to discover that males were guilty of more misconduct overall than females, but also found that in urban areas females had more instances of misconduct than male teachers, although they list mitigating factors that may have caused the greater number of urban female teachers as perpetrators that are unique to the Tanzanian context. It is also possible that female victims are more likely to report instances of abuse, as Winters, Clift and Maloney (2004) found was the case with victims of adult sexual harassment in British Columbia secondary schools. Winters et al. (2004) found that none of the males in their study who had experienced sexual harassment behaviour reported the behaviour to an adult, and only 13\% told anyone at all - in this case their friends. If female victims of abuse are more likely to be victimized by males, and are more likely than their male counterparts to report instances of abuse, that could be a partial explanation as to the overabundance of males facing disciplinary hearings.

When asked why males would not consider entering the teaching profession, one teacher responded: "possibility of false accusations of professional misconduct or sexual harassment." (Ontario College of Teachers, 2004, p. 17). In the same 2004 report, when asked about public perceptions of male teachers, all groups; students, teachers, and administrators, expressed concern about accusations of sexual misconduct. Writing in The Walrus about his feelings upon learning that a former teacher was convicted of sexual abuse, one male author reflected:

I sized up every man who interacted with my two sons, who are five and two. Neighbours, friends, relatives, and shop clerks were all suspect, but I reserved most of my scrutiny for the few male teachers at my elder son's elementary school. I questioned their motives for wanting to teach young children, and spent sleepless nights wondering how I would get my boys through school free of nefarious male authority figures. At one point, I thought I could micromanage their lives so all of their teachers would be female, and make maledominated team sports off limits. My response, however unreasonable, is hardly abnormal. (Nield, 2012, para. 6)

While suspicion of all male teachers is both unreasonable and unhealthy for the profession, most evidences does suggest that males are more likely to be the perpetrators of sexual offences. The Badgley Commission, which examined sexual abuse of Canadian Children in the 1980s found that "virtually all assailants are males; one in 100 is a female" (Badgley et al., 1984, p. 2). The 
resulting public distrust of male educators is widespread and has negative effects on our education system. Astor and Meyer (2001) found that male middle school teachers were reluctant to intervene in when two girls were fighting, for fear of sexual harassment allegations. A survey conducted by Parr and Gosse (2011) indicated that greater than $10 \%$ of the male teachers surveyed (28 out of 223) had been suspected at some point of having inappropriate contact with pupils. Since it is clear that, while they may be responsible for the majority of cases, males are not the only perpetrators of abuse, and it would be both impractical and undesirable to remove all males from the education system, we have to ensure that the public trusts those males worthy of trust that do choose to teach, and are certified. This is one of the many reasons the OCT and other teacher regulatory bodies must do their job well, and be seen by the public to be doing their job effectively.

To protect students, we need to move faster as a profession in dealing with teachers who do not respect the rights of students. An Alberta case heard in November 2018 dealt with complaints that went back as far as 1981. It was recommended that the teacher have her teaching certificate revoked. While it is unknown at this point if the teacher was guilty of regular ongoing misconduct since 1981, the possibilities regarding the potential number of students harmed is alarming. In Ontario College of Teachers $v$ Bondar (2002), concerns were first brought about in regards to the teacher in 1989, and yet the teacher was able to work at five different schools, was subject to multiple performance evaluations involving vice principals, principals, more than one superintendent, and seven days of hearings involving 13 witnesses, before she was finally found guilty of professional misconduct and had her certificate revoked 13 years after the initial concerns. In a separate case where the teacher had his Certificate of Qualification revoked after being found guilty of verbal abuse and other professional misconduct, (Ontario College of Teachers $v$. Lewis, 2017) the teacher had been cautioned by the school board in 2004, 2005, and 2007. This same teacher was also given a letter of caution in a similar matter in 2011, and again had to meet with the board in 2012, for incidents that had occurred in 2010 and 2011. Colleagues of this teacher submitted a written complaint to the college in 2012 and in 2014 a student reported an incident of inappropriate conduct to a child and youth worker. In 2015 the teacher again received a letter of caution from the school board in regards to his inappropriate comments, and his certificate was finally revoked in November 2017. In this case, the teacher was cautioned by his board three times in a period of four years, and continued to teach for nearly a decade after that. While it is unknown how much abuse occurred in those intervening years, at least one former student came to testify about what was thought to be a racist remark that occurred in 2008-2009 school year, which is in addition to the agreed upon facts already mentioned. While there are many other similar examples, a full recounting of them would not be purposeful, it is sufficient to note that there are enough cases to constitute a problem with speed of resolution. It should also be noted that recent changes to the Ontario College of Teachers Act (1996) have made provisions for more timely disposition of complaints, but in a case as recent as January 2019 (Ontario College of Teachers $v$ Miszkiel, 2019) the case has not been concluded even though, according to College counsel "the Notice of Hearing was issued two and a half years ago pertaining to conduct that occurred now four and five years ago," (para. 13). It is evident that the delay in effectively dealing with complaints and disciplinary matters is unacceptable as it stands, and must be fixed in order to protect a greater number of students from abuse.

\section{References}

Alberta Education. (2018). Accountability pillar results for annual education results report (AERR). Retrieved July 2019, from https://open.alberta.ca

Alberta Education. (2017). Accountability Pillar Jurisdiction Survey. Retrieved July 2019 from https://education.alberta.ca/media/3402244/2017-ap-survey-grade-4-6-student-samplew.pdf 
Alberta Teachers' Association (2004). Code of Professional Conduct. Retrieved July 2019 from https://www.teachers.ab.ca/SiteCollectionDocuments/ATA/Publications/Teachers-asProfessionals/IM-4E\%20Code\%20of\%20Professional\%20Conduct.pdf

Allen, J.L., Morris, A., \& Chhoa, C.Y. (2016). Callous-unemotional (CU) traits in adolescent boys and response to teacher reward and discipline strategies. Emotional and Behavioural Difficulties, 21(3), 329-242.

Allen, K.P. (2010). Classroom management, bullying, and teacher practices. The Professional Educator, 34(1) 115.

Aluede, O., Ojugo, A.I., \& Okoza, J. (2012). Emotional abuse of secondary school students by teachers in Edo State, Nigeria. Research in Education, 88(1), 29-39.

Astor, R.A., \& Meyer, H.A. (2001). The conceptualization of violence-prone school subcontexts: Is the sum of the parts greater than the whole? Urban Education, 36(3), 374-399.

Atiles, J.T., Gresham, T.M., \& Washburn, I. (2017). Values and beliefs regarding discipline practices: How school culture impacts teacher responses to student misbehaviour. Educational Research Quarterly, 40(3), 324.

Babad, E., Bernieri, F., \& Rosenthal, R. (1991). Students as judges of teachers' verbal and nonverbal behavior. American Educational Research Journal, 28(1), 211-234.

Badgley, R.F., Allard, H.A., McCormick, N., Proudfoot, P.M., Fortin, D., Ogilve, D., ... Sutherland, S. (1984) Sexual offences against children in Canada: Summary of the report of the committee on sexual offences against children and youths. Government of Canada. Retrieved July 2019 from https://www.attorneygeneral.jus.gov.on.ca

Bekiari, A., \& Petanidis, D. (2016). Exploring teachers' verbal aggressiveness through interpersonal attraction and students' intrinsic motivation. Open Journal of Social Sciences, 4, 72-85.

Betweli, O. (2013). The nature of teacher professional misconduct in Tanzanian public primary schools: The case of Sumbawanga municipal and rural districts. International Journal of Education, 5(1), 81-93.

Blase, J., \& Blase, J. (2004) School principal mistreatment of teachers: Teachers' perspectives on emotional abuse. Journal of Emotional Abuse, 4(3/4), 151-175.

British Columbia Teachers' Federation. (2017). BCTF Code of Ethics. Retrieved July 2019 from https:/ / bctf.ca/ProfessionalResponsibility.aspx?id=4292

Brendgen, M., Bukowski, W.M., Wanner, B., Vitaro, F., \& Tremblay, R.E. (2007). Verbal abuse by the teacher during childhood and academic, behavioral, and emotional adjustment in young adulthood. Journal of Educational Psychology, 99(1), 26-38.

Brendgen, M., Wanner, B., \& Vitaro, F. (2006). Verbal abuse by the teacher and child adjustment from kindergarten through grade 6. Pediatrics, 117(5), 1585-1598.

Canadian Charter of Rights and Freedoms (1982). Part I of the Constitution Act. Sup Ct L Rev, 4, 287-294.

Carr, P.R. (2008). The "Equity Waltz" in Canada: Whiteness and the informal realities of racism in education. Journal of Contemporary Issues in Education 3(2), 4-23.

Crowe, S., Cresswell, K., Robertson, A., Huby, G., Avery, A., \& Sheikh, A. (2011). The case study approach. BMC Medical Research Methodology, 11, 100. doi:10.1186/1471-2288-11-100

Elo, S., \& Kyngäs, H. (2008). The qualitative content analysis process. Journal of Advanced Nursing, 62(1), 107115.

Flyvbjerg, B. (2011). Case study. In Norman K. Denzin \& Yvonna S. Lincoln (Eds.), The Sage handbook of qualitative research (4th ed., pp.301-316). Thousand Oaks, CA: Sage.

French, J. (2018, November 27). Teacher found guilty of eight counts of unprofessional conduct over 36 years. Edmonton Journal. Retrieved June 2019, from https://edmontonjournal.com/news/localnews/sixty-witnesses-testify-against-teacher-found-guilty-of-eight-counts-of-unprofessional-conductover-36-years

Fromuth, M.E., Davis, T.L., Kelly, D.B., \& Wakefield, C. (2015). Descriptive features of student psychological maltreatment by teachers. Journal of Child and Adolescent Trauma, 8, 127-135.

Konishi, C., Hymel, S., Zumbo, B.D., \& Li, Z. (2010). Do school bullying and student-teacher relationships matter for academic achievement? A multilevel analysis. Canadian Journal of School Psychology, 25(1), 1939. http://dx.doi.org/10.1177/0829573509357550

LeSage, P.J. (2012). Review of the Ontario College of Teachers intake, investigation and discipline procedures and outcomes, and the dispute resolution program. Retrieved June 2019, from https://www.oct.ca/pdf/lesage_report_e.pdf

McKenzie, K.B. (2009). Emotional abuse of students of color: The hidden inhumanity in our schools. International Journal of Qualitative Studies in Education, 22(2), 129-143. 
Montgomery, K. (2013). Pedagogy and privilege: The challenges and possibilities of teaching critically about racism. Critical Education, 4(1). Retrieved from http://ojs.library.ubc.ca/index.php/criticaled/article/view/182323

Nesbit, W.C., \& Philpott, D.F. (2002). Confronting subtle emotional abuse in classrooms. Guidance $\mathcal{E}$ Counseling 17(2), 32-39.

Nield, J. (2012). Tough lessons: Reflections on a popular teacher with a dark secret. The Walrus. Retrieved June 2019, from https:/ / thewalrus.ca/tough-lessons /

Ontario College of Teachers Act. (1996) S.O. 1996, C. 12. Retrieved from https://www.ontario.ca/laws

Ontario College of Teachers. (n.d.) Resolving Complaints. Retrieved from https://www.oct.ca//media/PDF/Resolving\%20Complaints/Resolving_Complaints_e.pdf

Ontario College of Teachers. (2001) Sexual misconduct and the teaching profession: the college prepare its response to the Robins report. Professionally Speaking, 2001(1). Retrieved from https:// professionallyspeaking.oct.ca

Ontario College of Teachers. (2002). College issues first professional advisory. Professionally Speaking 2002(4). Retrieved from https:/ / professionallyspeaking.oct.ca

Ontario College of Teachers. (2003). Investigation Committee Deals With All Complaints. Professionally Speaking 2003 (2). Retrieved from https:/ / professionallyspeaking.oct.ca

Ontario College of Teachers. (2004). Narrowing the gender gap: Attracting men to teaching. Retrieved from https://www.oct.ca//media/PDF/Attracting\%20Men\%20To\%20Teaching/EN/Men_In_Teaching_e.pdf

Ontario College of Teachers. (2007a). Male presence in teaching continues to decline. Professionally Speaking, 2007(2). Retrieved from https:// professionallyspeaking.oct.ca

Ontario College of Teachers. (2007b). The first decade: 10 years, 10 accomplishments. Professionally Speaking, 2007(2). Retrieved from https:// professionallyspeaking.oct.ca

Ontario College of Teachers. (2013). Investigation committee deals with all complaints. Professionally Speaking, 2003(1). Retrieved from https:// professionallyspeaking.oct.ca

Ontario College of Teachers. (2014). Incapacity case study. Professionally Speaking, 2014(1), 58. Retrieved from https:// professionallyspeaking.oct.ca

Ontario College of Teachers. (2015). History of the Ontario College of Teachers. Retrieved from https://www.oct.ca/about-the-college/what-we-do/college-history

Ontario College of Teachers. (2017a). Disciplinary decisions now available on CanLII. Professionally Speaking, 2017(1), 48. Retrieved from https://professionallyspeaking.oct.ca/march_2017/ENG_PS01_2017_AODA_FINAL.pdf

Ontario College of Teachers. (2017b). Your fees at work. Professionally Speaking, 2017(1), 49. Retrieved from https://professionallyspeaking.oct.ca/march_2017/ ENG_PS01_2017_AODA_FINAL.pdf

Ontario College of Teachers. (2018). 2017 annual report of the Ontario College of Teachers. Retrieved from https://reports2017.oct.ca/

Ontario College of Teachers. (2019a). Complaints and Discipline. Retrieved from https://www.oct.ca/public/complaints-and-discipline

Ontario College of Teachers. (2019b). Discipline Decisions. Retrieved from https://www.oct.ca/public/complaints-and-discipline/decisions

Ontario College of Teachers v Blake, ONOCT 57 (2018). Retrieved from CanLII http://canlii.ca/t/hwx7c Ontario College of Teachers v Bondar, ONOCT 3 (2002). Retrieved from CanLII http://canlii.ca/t/gv6k4 Ontario College of Teachers v Caswill, ONOCT 3 (1999). Retrieved from CanLII http://canlii.ca/t/gv7ck Ontario College of Teachers v Fernandes, ONOCT 31 (2018). Retrieved from CanLII http://canlii.ca/t/ht7px Ontario College of Teachers v Gionest, ONOCT 92 (2017). Retrieved from CanLII http://canlii.ca/t/hq4vw Ontario College of Teachers v Glazer, ONOCT 37 (2018). Retrieved from CanLII http://canlii.ca/t/htt25 Ontario College of Teachers v Guirand, ONOCT 9 (1998a). Retrieved from CanLII http://canlii.ca/t/hvzr2 Ontario College of Teachers v Guirand, ONOCT 1 (1998b). Retrieved from CanLII http://canlii.ca/t/gvb7m Ontario College of Teachers v Korjus, ONOCT10 (2011). Retrieved from CanLII http://canlii.ca/t/gvd2x Ontario College of Teachers v Kuneman, ONOCT 4 (1998). Retrieved from CanLII http://canlii.ca/t/gvd31 Ontario College of Teachers v Lewis, ONOCT 94 (2017). Retrieved from CanLII http://canlii.ca/t/hq4w1 Ontario College of Teachers v Manga, ONOCT 48 (2017). Retrieved from CanLII http://canlii.ca/t/h4zgn Ontario College of Teachers v Markson, ONOCT 13 (2001a). Retrieved from CanLII http://canlii.ca/t/gvjs3 Ontario College of Teachers v Markson, ONOCT 14 (2001b). Retrieved from CanLII http://canlii.ca/t/gvjs2 Ontario College of Teachers v Miszkiel. ONOCT 06 (2019). Retrieved from CanLII http://canlii.ca/t/hzjn9 
Ontario College of Teachers v Montgomery, ONOCT 4 (2018). Retrieved from CanLII http://canlii.ca/t/hq977

Ontario College of Teachers v Mosley, ONOCT 6 (2018). Retrieved from CanLII http:/ / canlii.ca/t/gwss9

Ontario College of Teachers v Reinders, ONOCT 62 (2017). Retrieved from CanLII http://canlii.ca/t/h67wt

Ontario English Catholic Teachers Association. (2017). Workplace violence and harassment against teachers: results of a comprehensive members survey. Retrieved January 2019, from http://www.catholicteachers.ca/OECTA/media/pdfs/News/2017/OECTA\%20Survey

Ontario English Catholic Teachers Association. (2018). Handbook 2018/2019. Retrieved January 2019, from http://www.oecta.on.ca

Ontario Ministry of Education. (1995a). Royal Commission on Learning, Vol IV. Retrieved from http://www.edu.gov.on.ca/eng/general/abcs/rcom/main.html

Ontario Ministry of Education. (1995b, January 26). Royal Commission on Learning provides a blueprint for changing Ontario schools. Retrieved from http://www.edu.gov.on.ca/eng/general/abcs/rcom/news.html

Ontario Ministry of Education. (2018a, January 2). A survey for students in grades 7 to 12 about equity and inclusive education, bullying/harassment. Retrieved from http://www.edu.gov.on.ca/eng/safeschools/survey7to12.pdf

Ontario Ministry of Education. (2018b). Reporting and responding to incidents: A resource for board employees. Retrieved from http://www.edu.gov.on.ca/eng/safeschools/keepkidsafeschool.pdf

Ontario Student Trustees Association. (2017). Ontario student survey [Data file]. Retrieved from https://docs.google.com/forms/d/1ycLVy2251kCrRllm3OdtmPZYODp9BqeaynHsNrHo3is/edit\#respo nses

Ordre des enseignantes et des enseignants de l'Ontario c Mosley, ONOCT 6 (1998) Retrieved from CanLII http://canlii.ca/t/gwssb

Parr, M., \& Gosse, D. (2011). The perils of being a male primary/junior teacher: Vulnerability and accusations of inappropriate contact with students. McGill Journal of Education, 46(3), 379-394. Retrieved from http:// mje.mcgill.ca/

Poggenpoel, M. (2005). Obstacles in qualitative research: Possible solutions. Education, 126(2), 304-311.

Professional Misconduct. (1997). O Reg 437/97 Retrieved from http://canlii.ca/t/534ws

Protecting Students Act. (2016). S.O., 2016, c.24 Retrieved January 2019, from https://www.ola.org/sites/ default/files/node-files/bill/document/pdf/2016/2016-12/bill---text-41-2-en-b037ra.pdf

Robins, S.L. (2000). Protecting our students. Retrieved January 2019, from https://www.attorneygeneral.jus.gov.on.ca/english/about/pubs/robins/

Ryan, T.G., \& Goodram, B. (2013). The impact of exclusionary discipline on students. International Journal of Progressive Education, 9(3), 169-177.

Saskatchewan Teachers' Federation. (2006). Code of Professional Ethics. Retrieved January 2019, from http://www.skteacherregulation.ca/standards/code-of-professional-ethics/

Stake, R. E. (2006). Multiple case study analysis. New York, NY: Guilford.

Stillman, J.B. (2013). The elephant in the classroom. Education Next, 13(1), 36-41.

Tal, C. (2010). Case studies to deepen understanding and enhance classroom management skills in preschool teacher training. Early Childhood Education Journal, 38(2), 143-152. doi:10.1007/s10643-010-0395-z

Twemlow, S.W., Fonagy, P., \& Sacco, F.C. (2004). The Role of the bystander in the social architecture of bullying and violence in schools and communities. Annals of the New York Academy of Science, 1036(1), 215232. https://doi.org/10.1196/annals.1330.014

Ungar, M., Tutty, L.M., McConnell, S., Barter, K., \& Fairholm, J. (2009). What Canadian youth tell us about disclosing abuse. Child Abuse \& Neglect, 33(10), 699-708.

Vaaland, G.S. (2016). Pupil aggressiveness, teacher authority, and disruptive classroom behaviour (Doctoral dissertation, University of Stavanger, Stavanger, Norway) Retrieved January 2019, from Brage https://brage.bibsys.no/xmlui/bitstream/handle/11250/2425272/Grete_Soerensen_

Vaaland.pdf?sequence $=4$

Webster, S.W., O'Toole, R., O'Toole, A.W., \& Lucal, B. (2005). Overreporting and underreporting of child abuse: Teachers' use of professional discretion. Child Abuse $\mathcal{E}$ Neglect, 29(11), 1281-1296. https://doi.org/10.1016/j.chiabu.2004.02.007

Wheeler, G.B. (1935). Yelling teachers. Journal of Education, 118(1), 7-7.

White, K.J., Jones, K., \& Sherman, M.D. (1998). Reputation information and teacher feedback: their influences on children's perceptions of behavior problem peers. Journal of Social and Clinical Psychology, 17(1), 11-37. 
Winters, J., Clift, R.J.W., \& Maloney, A. (2004). Adult-student sexual harassment in British Columbia high schools. Journal of Emotional Abuse, 4(3/4), 177-196.

Wright, C. (2018, July 5). Mom's secret recording catches kindergarten teacher calling 5-year-old a 'loser'. Miami Herald. Retrieved from https://www.miamiherald.com 